\title{
People's Clean and Healthy Behaviors during the COVID-19 Outbreak: A Case Study in DKI Jakarta Province
}

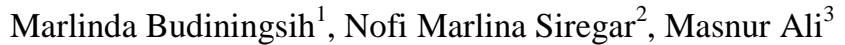 \\ \{mbudiningsih@unj.ac.id ${ }^{1}$, nofims@unj.ac.id ${ }^{2}$, ali.masnur@unj.ac.id ${ }^{3}$ \} \\ Universitas Negeri Jakarta, Jakarta, Indonesia ${ }^{123}$
}

\begin{abstract}
Since the coronavirus novel case was first announced by the Government of the Republic of Indonesia, we conducted research that aims to find out the impact of the novel coronavirus towards people's clean and healthy behaviors in DKI Jakarta Province. Random sampling was used in this study with samples $(\mathrm{n}=349)$ who filled in online questions via Google Form. To date (1st June 2020), there is no vaccine or no specific treatment for COVID-19. Therefore, efforts to prevent transmission of SARS-CoV-2 can be done by applying a clean and healthy life culture. This research show the culture is reflected in the behavior of washing hands, consuming nutritious food, exercising regularly and getting enough rest, not smoking and avoiding cigarette smoke, as well as maintaining environmental hygiene and personal hygiene has been carried out by the community of the Province of DKI Jakarta. Preparedness should be a priority for future pandemic outbreak.
\end{abstract}

Keywords: DKI Jakarta Province, SARS-CoV-2, COVID-19, Clean and Healthy Life Behavior

\section{Introduction}

In 2020 a significant threat to public health emerged [1].The outbreak was officially reported to occur in the late 2019, on 31 December 2019, a case of pneumonia with clinical symptoms of patients such as dry cough, dyspnea and fever whose unknown etiology was identified in Wuhan City, Hubei Province in China [2, 3]. Chinese scientist reported that the virus had $96,3 \%$ genetic similarity with a Yunnan bat coronavirus RaTG13 and 70\% homology with severe acute respitory syndrome coronavirus (SARS-CoV), cause this epidemic outbreak was discovered in 2019 then World Health Organization named the disease as COVID-19 short for "coronavirus disease 2019" [4, 5]. COVID-19 was initially identified to spread through animals because the identified patients' history have links to Wuhan's Huanan Seafood Wholesale Market that sells fish and various live animals such as poultry, bats, guinea pigs and snakes [6]. However, further investigations revealed that some people who contracted the infection had no track record of visiting the market, indicating that the spread of the virus from human to human was possible [7]. The spread occurs due to close contact with an infected person by spreading through respiratory secretions, 
such as how influenza (flu) spreads, people with COVID-19 have symptoms of fever, coughing, muscle aches, headaches and diarrhea, so initially it will be difficult to distinguish disease COVID-19 with other viral infections such as flu [8].

The World Health Organization (WHO) has confirmed a total of 2,954,222 infected cases with 202,597 deaths during the coronavirus outbreak occurred throughout the world [9]. Indonesia reported 2 positive cases of COVID-19 for the first time on March 2, 2020 [10]. To date (29th April 2020) there were 9,511 positive cases, 7,484 patients were in treatment, 1,254 patients had recovered, and 773 cases had died due to the virus, the emergence and spread of COVID-19 occurred to almost all of the world is a global pandemic threat $[11,12]$. Up to the date this article was written, DKI Jakarta Province is the highest area in Indonesia with confirmed COVID-19 cases reaching up to 4,033 positive cases, 2,002 patients in treatment, 412 patients recovered, 381 cases died due to viruses and 1,238 independently isolated patients [13]. The first case of COVID-19 in Indonesia occurred in DKI Jakarta Province, the patient was suspected of being infected by a foreign citizen, who was identified positively after being examined abroad. After that, imported cases from people returning from traveling abroad started to be discovered [14].

In an effort to reduce the spread of COVID-19, the DKI Jakarta Provincial Government issued an initial press release in taking fast and responsive steps, they officially adopted Large-scale social restrictions that were applied for 14 days on April $10,2020[15,16]$. In addition to large-scale restrictions, WHO also recommends maintaining environmental hygiene and personal health such as the availability of clean water, waste management and sanitation, maintaining environmental hygiene and ensuring regular hand washing that can help prevent, slow down and stop the spread of COVID-19 outbreaks from humans to humans $[17,18]$.

During the pandemic period in DKI Jakarta Province, research on clean and healthy behavior in the community during the COVID-19 outbreak was very limited. This study aims to find out the culture of clean and healthy behavior carried out by the people of DKI Jakarta province during the pandemic, which is expected to reduce the spread of COVID-19. Clean and healthy life behavior suggested by the government of the Republic of Indonesia and WHO is one of the important indicators to reduce the spread of the virus. Therefore, people of DKI Jakarta Province as the epicenter with the highest spread of COVID-19 in Indonesia, are obliged to comply with health protocols by taking care of their own health, one of them through cultural activities of clean and healthy living.

This study only covered less than ten percent of the total population of DKI Jakarta Province. Therefore, through the results of this study, it is hoped that the Provincial Government of DKI Jakarta will be able to increase public awareness to keep conducting clean and healthy behavioral activities as part of COVID-19 prevention efforts.

\section{$2 \quad$ Method}

We collected data information from samples $(n=349)$ who are domiciled in DKI Jakarta Province using random sampling techniques. Electronic surveys in the form of Google forms, data collection was carried out by distributing electronic ques- 
tionnaires through social media networks from 19 to 27 April 2020 in DKI Jakarta in general. The sample size was determined by using the Issac and Michael tables for an error rate of 5\% [19], obtained a minimum number of 349 samples from 10,557,810 populations of DKI Jakarta Province [20]. Respondents were asked about knowledge of the COVID-19 outbreak, symptom screening, prevention protocols, and clean and healthy living behaviors during the COVID-19 outbreak such as washing hands, consumption of balanced nutritious food, regular exercise and adequate rest, avoidance of smoking and inhaling cigarette smoke, and also maintaining environmental cleanliness.

Responses are shown on a 5-point scale Likert-type with anchor rank $(1=$ strongly disagree, 2 = disagree, $3=$ doubtful, 4 = agree, $5=$ strongly agree), the statements are dichotomized to be high (4-5) and low (1-3). Respondents completed demographic items including gender, age, education, and occupation. All data were processed using IBM SPSS Windows 26 version statistics. Fifteen percent of the processed data was checked for validity and no errors were found. Descriptive statistics are reported to find out the relationship between the COVID-19 issue and the clean and healthy behavior of the people of DKI Jakarta Province during the COVID-19 outbreak.

\section{$3 \quad$ Result}

Data collected from the electronic survey form totaled to 349 respondents, with respondent demographics were as follows: $62.5 \%$ male respondents and $37.5 \%$ female respondents. The average age of respondents is 24 years with a standard error of 0.430 . Based on the characteristics of the respondents' education level of $82.8 \%$ respondents had graduated from high school/vocational school/MA and $13.2 \%$ of respondents had graduated from D4/S1. Characteristics of the respondents' work type are $75.4 \%$ as students and $8.3 \%$ as private employees.

Based on the results of research data processing, it is known that $87.0 \%$ of respondents know information regarding new viruses that are endemic in DKI Jakarta Province, $89.0 \%$ of respondents know the symptoms caused by viruses so that they can do early screening if contracted by the virus, $75.0 \%$ of respondents know how to prevent so as to avoid contracting the virus. The results related to clean and healthy life behavior during the COVID-19 pandemic period are stated in five indicators namely as many as $89.0 \%$ of respondents did hand washing more frequently than usual during the COVID-19 outbreak, $86.3 \%$ of respondents consumed nutritious food and health supplements with the aim to maintain immunity during the COVID-19 outbreak, $78.2 \%$ of respondents do regular exercise and adequate rest to avoid the virus, $83.9 \%$ of respondents do not smoke and avoid cigarette smoke, and $80.0 \%$ of respondents always maintain personal hygiene and the environment. Based on these results it can be concluded that there is a significant influence ( $p$-value $=.000$ ) between the COVID-19 issue and the clean and healthy behavior of the community during the COVID-19 outbreak.

Characteristics and knowledge of respondents about COVID-19 as well as a clean and healthy living behavior is shown in Table 1 . 
Table 1. People's Clean and Healthy Behaviors During the COVID-19 Outbreak ( $n=349)$

\begin{tabular}{|c|c|c|c|}
\hline \multirow{2}{*}{ Characteristics } & Entire & Female & \multirow{2}{*}{$\frac{\text { Male }}{\%}$} \\
\hline & \multirow{2}{*}{$\%$} & $\%$ & \\
\hline Total & & 37.5 & 62.5 \\
\hline \multicolumn{4}{|l|}{ Information of Covid-19 Outbreak } \\
\hline High (4-5) & 87.0 & 85.7 & 88.4 \\
\hline Low $(1-3)$ & 13.0 & 14.3 & 11.6 \\
\hline \multicolumn{4}{|l|}{ Symptom Screening } \\
\hline $\operatorname{High}(4-5)$ & 89.0 & 88.3 & 89.7 \\
\hline Low (1-3) & 11.0 & 11.7 & 10.3 \\
\hline \multicolumn{4}{|l|}{ Prevention of Contracting } \\
\hline High (4-5) & 75.0 & 75.1 & 74.8 \\
\hline Low (1-3) & 25.0 & 24.9 & 25.2 \\
\hline \multicolumn{4}{|l|}{ Hand Washing } \\
\hline High (4-5) & 89.0 & 86.6 & 91.3 \\
\hline Low (1-3) & 11.0 & 13.4 & 8.7 \\
\hline \multicolumn{4}{|l|}{ Consumption of Nutritious Foods } \\
\hline High (4-5) & 86.3 & 82.1 & 90.5 \\
\hline Low (1-3) & 13.7 & 17.9 & 9.5 \\
\hline \multicolumn{4}{|l|}{ Regular Exercise and Adequate Rest } \\
\hline High (4-5) & 78.2 & 76.5 & 79.9 \\
\hline Low (1-3) & 21.8 & 23.5 & 20.1 \\
\hline \multicolumn{4}{|c|}{ Do not Smoke and Avoid Cigarette Smoke } \\
\hline High (4-5) & 83.9 & 79.2 & 88.5 \\
\hline Low $(1-3)$ & 16.1 & 20.8 & 11.5 \\
\hline \multicolumn{4}{|c|}{ Maintaining Environmental Cleanliness } \\
\hline High (4-5) & 80.0 & 81.1 & 78.9 \\
\hline Low (1-3) & 20.0 & 18.9 & 21.1 \\
\hline
\end{tabular}

\section{Discussion}

Based on the age characteristics of the respondent, the age range of 14-29 years old is the age of $15 \%$ of positive cases in Indonesia, while the largest percentage of positive cases (54\%) are in the age group of 30-59 years [21]. The high percentage of positive cases in Indonesia makes $87.0 \%$ of respondents in need of information about the COVID-19 outbreak. Information literacy is needed in accessing, utilizing and disseminating various information related to COVID-19, originating from reliable sources from both the Central Government and Regional Governments so that through accurate information on an issue can make individuals become disciplined in dealing with that particular issue. [22, 23]. The information in question is the accessibility of one of the pages owned by the Provincial Government of DKI Jakarta, namely https://corona.jakarta.go.id. On this page there is information about screening for early symptoms of the COVID-19 virus that aims to identify diseases that have not been recognized by humans by applying tests or examination that can be applied quickly using the method of questions about the cause of the disease or medical and journey history $[24,25]$. By using this page, $89.0 \%$ of respondents were able to screen for the initial symptoms of COVID-19. 
Based on the appeal from the World Health Organization, we can prevent transmission of the virus by taking several actions such as 1) cleaning hands with antiseptic as well as soap and running water; 2) do the protocol to keep a distance of at least 1 (one) meter from the others; 3 ) avoid activities in the crowds; 4) avoid touching eyes, nose and mouth; 4) make sure we and the people around us keep our nose and mouth hygiene; 5) stay home when potentially suffering from cough, headache, itchy throat until it feels healed [26,27]. The appeal for prevention is carried out because of the limited knowledge of the newly discovered viruses and as a key of prevention by doing individual basic protection [28]. Efforts to increase knowledge, screening for symptoms and acting in prevention are related to what is referred to as healthy behavior, namely efforts to improve and maintain health and attitudes in responding to health actions such as individual evaluations of matters relating to health and direct actions to obtain a healthy life [29].

Washing hands is one indicator of clean and healthy living behavior as fingers can be a pathway for pathogens, bacteria and viruses [30], washing hands with soap has been proven to reduce diarrheal diseases and acute respiratory infections [31]. Apart from soap, hand sanitizers can be used in avoiding COVID-19 transmission [27]. Therefore, $89.0 \%$ of respondents have taken precautions to prevent transmission of the COVID-19 virus by washing their hands at certain times.

Cases of death at Renmin Hospital of Wuhan University show that age and congenital illnesses of patients such as hypertension, diabetes, heart disease, kidney disease, stroke, COPD, tumors, and acute pancreatic disease are risk factors causing death [32]. Therefore, endurance and good body condition are needed to prevent transmission of COVID-19. Someone with a good diet will have a better immune system compared to people with a poor diet, the principle of a healthy diet are safe, nutritious, diversed and balanced [33]. Adequacy of nutrition, especially vitamins and minerals is needed in maintaining an optimal immune system as a preventive effort to always be healthy [34].

Strong endurance is one factor that can avoid the COVID-19 virus, regular exercise with a frequency of 3-5 times per week that is done with moderate intensity and duration not too long around 30-45 minutes can be a way to maintain health, fitness and endurance [35]. A good exercise is when the heart rate works between $60-80 \%$ of the maximum heart rate with a length of exercise between 30 to 60 minutes, excessive regular exercise will make the body become tired that it can cause pain [36]. Enough rest is also a factor that can maintain a healthy body, because adequate rest will help avoid various diseases such as heart disease, high blood pressure, stroke and even diabetes [37].

Smoking habit can reduce life span by half, because smoking can cause: 1) hair loss; 2) cataracts; 3) early hearing loss; 4) chronic lung damage; 5) damage teeth and bad breath; 6) stroke and heart attack; 7) make bones break more easily; 8) skin cancer and; 9) impotence disorders and pregnancy and even uterine cancer [38,39]. In addition to active smokers, passive smokers can also suffer from various diseases, based on WHO's call that there are diseases caused by cigarette smoke such as: 1) lung cancer; 2) asthma; 3) chronic obstructive pulmonary disease; 4) tuberculosis; 5) other respiratory diseases and decreased lung function [40]. There are no studies linking the risk of SARS-CoV-2 infection with smoking. However, tobacco smokers are more susceptible 
to COVID-19 due to finger contact (contaminated cigarettes) with the lips which increases the likelihood of hand-to-mouth transmission of the virus [41].

Maintaining environmental cleanliness during the outbreak of COVID-19 can help prevent the spread of the virus as cleaning dirty surfaces using cleaning soap and water so as to reduce germs, dirt and stains, while cleaning the surface with disinfectant (recommended that meets the EPA standard criteria) is able to kill germs and viruses $[17,42]$. In addition to cleaning the surface of objects in the home environment, Hong Kong's Center for Health Protection advises people to maintain drainage pipes on a regular basis by pouring water into the drain and putting toilet covers before rinsing with the aim of avoiding the spread of germs [43]. Tissue or other materials used when sneezing and coughing must be thrown into the trash as soon as possible or put in trash that is tightly bound in a black bag before being disposed of and taken by environmental cleaners, then hand hygiene must be maintained after carrying out the waste disposal activity [17].

\section{Conclussion}

This research proves that the activities of washing hands, consuming nutritious food, exercising regularly and resting adequately, not smoking and avoiding cigarette smoke and maintaining environmental hygiene have been carried out by the people of DKI Jakarta Province. The clean and healthy life culture carried out by the people of DKI Jakarta Province is one of the efforts to prevent the spread of COVID-19, even though the data compiled from the DKI Jakarta Provincial Government website related to the number of positive sufferers of COVID-19 did not experience a significant decrease. Through this research it can be seen that the issue of COVID-19 can influence clean and healthy life behavior in the community.

The clean and healthy living behavior like washing hands, consuming nutritious food, exercising regularly and getting enough rest, not smoking and avoiding cigarette smoke, and maintaining environmental cleanliness and personal hygiene are among the preventive actions that are easily carried out by each individual.

The subject of this study only targets less than 10 percent of the population in DKI Jakarta Province. Therefore, greater efforts are needed that focus on prevention rather than treatment by conducting health promotion aimed at changing public perceptions about maintaining hygiene and health as a way to prevent infectious diseases [44].

\section{References}

[1] Elengoe A. COVID-19 Outbreak in Malaysia. Osong Public Heal Res Perspect 2020;11:93-100.

[2] Lee A. Wuhan novel coronavirus (COVID-19): why global control is challenging? Public Health 2020;179:A1-2.

[3] Sohrabi C, Alsafi Z, O'Neill N, Khan M, Kerwan A, Al-Jabir A, et al. World Health Organization declares global emergency: A review of the 2019 novel coronavirus (COVID-19). Int J Surg 2020;76:71-6. https://doi.org/10.1016/j.ijsu.2020.02.034.

[4] Singhal T. A Review of Coronavirus Disease-2019 (COVID-19). Indian J Pediatr 2020;87:281-6. 
[5] WHO. Cronavirus disease (COVID-19) Situation Report-22. WHO Bull 2020.

[6] Lu H, Stratton CW, Tang YW. Outbreak of pneumonia of unknown etiology in Wuhan, China: The mystery and the miracle. J Med Virol 2020;92:401-2.

[7] Shereen MA, Khan S, Kazmi A, Bashir N, Siddique R. COVID-19 infection: Origin, transmission, and characteristics of human coronaviruses. J Adv Res 2020;24:91-8.

[8] Thompson LA, Rasmussen SA. What Does the Coronavirus Disease 2019 (COVID-19) Mean for Families? JAMA Pediatr 2020;2019:2020.

[9] Tomar A, Gupta N. Prediction for the spread of COVID-19 in India and effectiveness of preventive measures. Sci Total Environ 2020;728:138762.

[10] Tosepu R, Gunawan J, Effendy DS, Ahmad LOAI, Lestari H, Bahar H, et al. Correlation between weather and Covid-19 pandemic in Jakarta, Indonesia. Sci Total Environ $2020 ; 725$.

[11] Chakraborty I, Maity P. COVID-19 outbreak: Migration, effects on society, global environment and prevention. Sci Total Environ 2020;728:138882.

[12] Kemenkes RI. Peta Sebaran COVID-19 2020.

[13] Diskominfotik PDJ. Data Pemantauan COVID-19 DKI Jakarta 2020.

[14] Vermonte P. Karakteristik dan Persebaran COVID-19 di Indonesia: Temuan Awal. Jakarta: 2020.

[15] Diskominfotik PDJ. Siaran Pers Nomor 1090/SP-HMS/03/2020. DKI Jakarta: 2020.

[16] Diskominfotik PDJ. Siaran Pers No 1191/SP-HMPS/04/2020. DKI Jakarta: 2020.

[17] WHO. Water, sanitation, hygiene and waste management for the COVID-19 virus. 2020.

[18] WHO. Critical preparedness, readiness and response actions for COVID-19 . 2020.

[19] Sugiyono. Metode Penelitian Kuantitatif, Kualitatif, dan R\&D. 23rd ed. Bandung: Alfabeta; 2016.

[20] Airlangga B. Provinsi DKI Jakarta Dalam Angka 20202020.

[21] Idhom AM. Update Corona Indonesia 30 April 2020 \& Data Covid-19 Dunia Terkini 2020.

[22] Ngafifi M. Kemajuan Teknologi Dan Pola Hidup Manusia Dalam Perspektif Sosial Budaya. J Pembang Pendidik Fondasi Dan Apl 2014;2:33-47.

[23] Subarjo AH. Perkembangan Teknologi dan Pentingnya Literasi Informasi untuk Mendukung Ketahanan Nasional. J Ilm Bid Teknol ANGKASA 2017;IX:1-8.

[24] Dinkes DJ. Informasi COVID-19 Dinas Kesehatan DKI Jakarta 2020.

[25] Maulani J. Aplikasi Kesehatan Menggunakan Metode Epidemiologi Skrining Tes Untuk Karyawan Cv.Annisa. Technol J Ilm 2019;10:10-6.

[26] Susilo A, Rumende CM, Pitoyo CW, Santoso WD, Yulianti M, Sinto R, et al. Coronavirus Disease 2019: Tinjauan Literatur Terkini Coronavirus Disease 2019: Review of Current Literatures. J Penyakit Dalam Indones 2020;7:45-67.

[27] WHO. Coronavirus disease (COVID-19) advice for the public 2020.

[28] Kemenkes. Pedoman kesiapan menghadapi COVID-19. Maret 2020. Jakarta: Direktorat Jenderal Pencegahan dan Pengendalian Penyakit (P2P); 2020.

[29] Putri Lina H. Perilaku Hidup Bersih dan Sehat (PHBS) Siswa Di SDN 42 Korog Gadang Kecamatan Kuranji Padang 2016;4:92-103.

[30] Octa A, Widi A. Hubungan Pengetahuan dan Sikap terhadap Perilaku Cuci Tangan pada Masyarakat Kelurahan Pegirian 2019;7:1-11.

[31] Freeman MC, Stocks ME, Cumming O, Jeandron A, Higgins JPT, Wolf J, et al. Systematic review: Hygiene and health: Systematic review of handwashing practices worldwide and update of health effects. Trop Med Int Heal 2014;19:906-16.

[32] Li X, Wang L, Yan S, Yang F, Xiang L, Zhu J, et al. Clinical characteristics of 25 death cases with COVID-19: A retrospective review of medical records in a single medical center, Wuhan, China. Int J Infect Dis 2020;94:128-32.

[33] Muhammad DRA. Pola Makan Sehat dan Bergizi untuk Meningkatkan Imunitas saat Terserang Covid-19. UNS 2020. 
[34] Siswanto S, . B, Ernawati F. Peran Beberapa Zat Gizi Mikro Dalam Sistem Imunitas. Gizi Indones 2013;36:57-64.

[35] Sofro ZM. Pakar UGM Bagi Tips Olahraga di Tengah Pandemi Covid-19. UGM 2020.

[36] Suharjana S. Kebiasaan Berperilaku Hidup Sehat Dan Nilai-Nilai Pendidikan Karakter 2012:189-201.

[37] Omeoo. Memetik Manfaat Tidur. P2ptm Kemkes RI 2016.

[38] Utari DT. Hubungan Antara Pengetahuan Remaja Tentang Perilaku Hidup Bersih dan Sehat (PHBS) di Sekolah dengan Kebiasaan Merokok di SMP Negeri 7 Samarinda. Universitas Muhammadiyah Kalimantan Timur, 2018.

[39] Wijaya AM. Data dan Situasi Rokok (Cigarette) Indonesia Terbaru. 15 Mei 2013.

[40] WHO. Tubuh tembakau. 2019.

[41] WHO. WHO statement: Tobacco use and COVID-19. 2020.

[42] National Center for Immunization and Respiratory Diseases D of VD. Cleaning And Disinfecting Your Home. 2020.

[43] Regan H. How can the coronavirus spread through bathroom pipes? Experts are investigating in Hong Kong. CNN 2020.

[44] Bloomfield SF, Rook GAW, Scott EA, Shanahan F, Stanwell-Smith R, Turner P. Time to abandon the hygiene hypothesis: New perspectives on allergic disease, the human microbiome, infectious disease prevention and the role of targeted hygiene. Perspect Public Health 2016;136:213-24. 